\title{
Gastric ischemia due to critical stenosis of the celiac trunk
}

\section{Isquemia gástrica secundaria a estenosis crítica del tronco celíaco}

doi.org/10.23938/ASSN.0248

\author{
C. Saldaña Dueñas, A. Elosua González, A. Guerra Lacunza
}

\begin{abstract}
Gastric ischemia (GI) results from diffuse or localized vascular insufficiency caused by different aetiologies such as systemic hypotension, vasculitis, disseminated thromboembolism and celiac or mesenteric stenosis. We present a case of gastric ischemia due to critical stenosis of the celiac artery treated using endovascular therapy. The celiac artery is the first major branch of the abdominal aorta and provides some of the blood supply to the stomach through the left gastric artery and other organs like the spleen (splenic artery branch) and the liver. Although the collateral blood supply to the stomach is protective, systemic hypotension or occlusion of the main arteries, as in the case of our patient, may result in gastric ischemia. The stent placement is an alternative to surgery in patients with high comorbidity and with good outcomes. The clinical awareness of this syndrome will allow gastroenterologists and radiologists to appropriately diagnose and manage affected patients.
\end{abstract}

Keywords. Gastric ischemia. Gastric ulcer. Celiac trunk stenosis. Endovascular stent.

\begin{abstract}
RESUMEN
La isquemia gástrica resulta de la insuficiencia vascular difusa o localizada causada por diferentes etiologías como la hipotensión sistémica, la vasculitis, el tromboembolismo diseminado y la estenosis mesentérica o celíaca. Presentamos un caso de isquemia gástrica secundaria a estenosis crítica del tronco celíaco tratada endovascularmente. El tronco celíaco es la primera rama de la aorta abdominal y aporta gran parte del flujo de sangre al estómago a través de la arteria gástrica izquierda y de otros órganos como el bazo (a través de la rama esplénica) y el hígado. Aunque las colaterales que irrigan el estómago son protectoras, la hipotensión sistémica o la oclusión de las principales ramas como en el caso que presentamos, pueden llevar a la isquemia gástrica. La colocación de stents endovasculares es una alterativa terapéutica a la cirugía en pacientes con gran comorbilidad y con buenos resultados. La sospecha clínica de este síndrome puede llevar tanto a gastroenterólogos como a radiólogos a un correcto diagnóstico y tratamiento de los pacientes afectos.
\end{abstract}

Palabras clave. Isquemia gástrica. Úlcera gástrica. Estenosis del tronco celíaco. Stent endovascular.
Servicio de Digestivo. Complejo Hospitalario de Navarra

Recepción: 09/10/2017

Aceptación provisional: 11/12/2017

Aceptación definitiva: 09/02/2018

\section{Correspondencia:}

Cristina Saldaña Dueñas

Servicio de Digestivo

Complejo Hospitalario de Navarra

Irunlarrea 3

31008 Pamplona

e-mail: crisaldu@hotmail.com 


\section{INTRODUCTION}

Gastric ischemia (GI) results from diffuse or localized vascular insufficiency caused by different etiologies such as systemic hypotension, vasculitis, disseminated thromboembolism or celiac or mesenteric stenosis ${ }^{1-4}$. We present a case of gastric ischemia due to critical stenosis of the celiac artery with an endovascular therapy approach.

\section{CASE REPORT}

A 66-year-old woman presented at the emergency department and postprandial acute diffuse abdominal pain followed by three episodes of hematemesis. She had previous history of type II diabetes, isquemic heart disease and peripheral arteriopathy with chronic ischemia of the lower limbs.

On admission, the patient was hemodynamic stable and her physical examination was unremarkable, except for epigastric and left hypo- chondrium tenderness to light palpation without rebound. Laboratory test revealed haemoglobin (Hb) of $8.9 \mathrm{~g} / \mathrm{dL}$, urea of $128 \mathrm{mg} / \mathrm{dL}$, serum creatitine of $2.4 \mathrm{mg} / \mathrm{dL}$ and mild elevation of transaminases with no other significant abnormalities. Two packed red blood cells were transfused.

Urgent esophagogastroduodenoscopy (EGD) was performed and a duodenal hemorrage was suspected due to the presence of fresh blood clots. Gastric alimentary content impaired proper visualization of gastric walls. A second EGD revealed a large and deep ulcer, from the lesser curvature to the incisura angularis, with endoscopic signs of recent bleeding (Fig. 1a) suggestive of ischemic origin that was confirmed by histological examination.

Further evaluation by computed tomography (CT) scan revealed splenic infarctions.

The combination of suspected GI, impaired liver enzymes and splenic infarctions suggested the implication of the celiac trunk. Furthermore, calcified atheromatosis of the aorta and its main abdominal branches were present in previous radiologic studies.

An endovascular approach was conducted: a stent graft was placed in the celiac trunk after

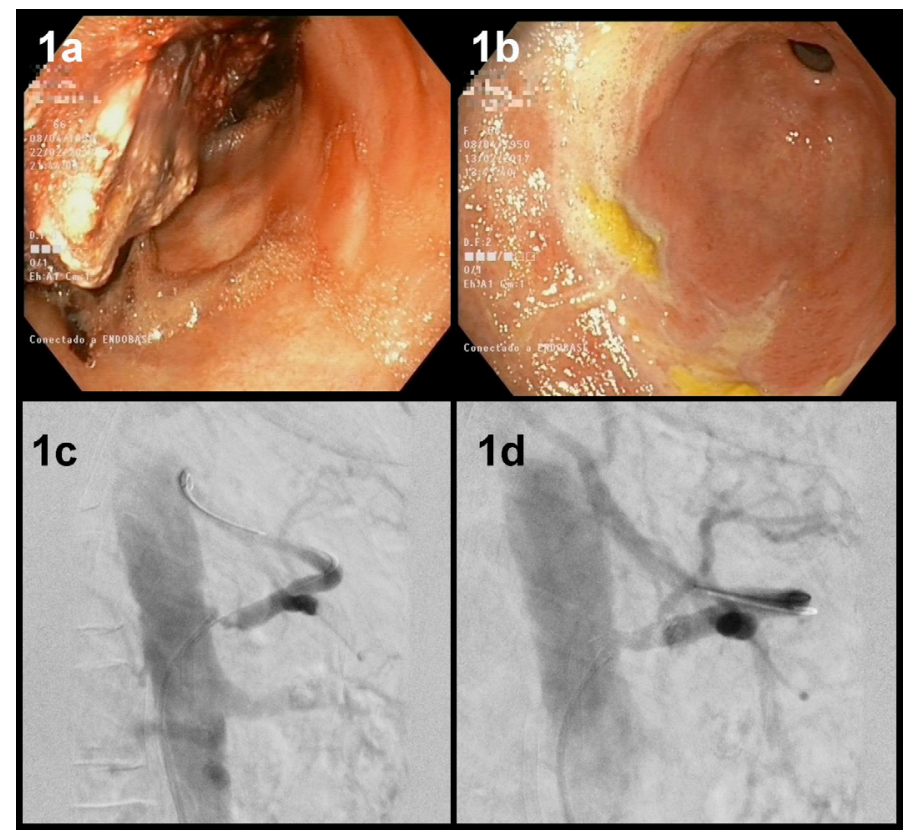

Figure 1. a: Esophagogastroduodenoscopy (EGD) image identifying blood clots and a gastric ulcer with endoscopic signs of recent bleeding; b: EGD findings of an ulcer in healing period; c: Angiography study with a critical stenosis of celiac trunk; d: Angiography where a stent graft was placed in the celiac trunk after loading dose of clopidogrel. 
loading dose of clopidogrel (Fig. 1c, 1d). After the procedure, the patient had a new episode of hematemesis with hemodynamic instability and anemization $(\mathrm{Hb}$ of $8.7 \mathrm{~g} / \mathrm{dL}$, being $11 \mathrm{~g} / \mathrm{dL}$ previously). She underwent a new EGD with an active upper gastrointestinal bleeding coming from an ischemic ulcer in the fundus-proximal gastric body. An ulcer in healing period was present in the lesser curvature (Fig. 1b). Another two concentrated red blood cells were transfused and antiplatelet therapy was discontinued. After 24 hours without symptoms and without bleeding, a third episode of hematemesis was followed by a haemorrhagic shock. No active bleeding was detected in the urgent angiography and the EGD revealed an endoscopically non-treatable haemorrhage. Urgent surgery was performed: large gastrostomy in the anterior wall visualizing an extensive lesion with detachment of the necrotic mucosa, affecting gastric fundus and body. After haemosthasia and closure, the patient was admitted to the intensive care unit where she experienced a new haemorrhagic shock non-treatable endoscopically. A surgical total gastrectomy was completed followed by a deteriorating clinical course. The patient died three days after surgery.

\section{DISCUSSION}

GI is mainly located at both the anterior and posterior gastric walls near the anastomoses between the two arterial arches over the lesser and greater curvature ${ }^{1,3}$.

GI results from diffuse or localized vascular insufficiency caused by different etiologies that may be classified by systemic hypoperfusion (such as shock or sepsis) or splanchnic vessel hypoperfusion secondary to gastric volvulus, acute gastric dilatation, stenosis, thrombosis, embolism, vasculitis or vasoconstriction ${ }^{3,4}$. Other rare causes of GI include endoscopic interventions (endoscopic submucosal dissection, injection sclerotherapy), postoperative conditions (distal pancreatectomy with celiac axis resection, subtotal gastrectomy, highly selective vagotomy, splenectomy, gastric restrictive procedure using staplers, esophageal surgery) and even cocaine abuse $\mathrm{e}^{3,4}$.

The celiac artery is the first major branch of the abdominal aorta and gives some of the stomach blood supply through the left gastric artery and also other organs as the spleen (by the splenic artery branch) and the liver (by the common hepatic artery $)^{1}$. Although the collateral blood supply to the stomach is protective, systemic hypotension or occlusion of the main arteries, as the case of our patient, may result in $\mathrm{GI}^{2}$.

The development of the ischemia leads into main symptoms such as abdominal pain, ulcers, gastrointestinal bleeding, and even perforation ${ }^{2-5}$. The progression of the vascular occlusion can manifest as either acute or chronic abdominal angina. In acute GI, patients can develop nausea, vomiting, upper gastrointestinal bleeding, abdominal distention, and symptoms and signs related to underlying predisposing conditions such as hypoperfusion or shock. In chronic GI, that may present as ischemic gastroparesis, patients usually develop abdominal pain, nausea, vomiting, overt or occult gastrointestinal bleeding, anemia, diarrhoea, and weight loss ${ }^{3,4}$.

The diagnosis is based on endoscopic and radiological examination and may be confirmed by anatomophatological study of biopsies. The CT scan findings comprise gastric wall thickening as the result of focal ulceration of the mucosa, intramural gas, gastric dilatation or even perforation ${ }^{1}$. Other radiological signs are thumbprinting, mucosal enhancement, intramural air, dilatation and portal venous gas. CT scan helps in determining the etiology of ischemia in some cases. Findings such as thrombosis, extensive vascular calcifications or tumour progression may guide specific therapeutic modalities in certain clinical scenarios ${ }^{4}$.

Endoscopic findings vary on the etiology and chronicity. Early EGD could found the ischemia, as ulceration development may take one to two days. It is a safe procedure as in ischemic colitis, even though the gastric wall is much thicker than the colonic wall. EGD also provides therapeutical options, for example in active bleeding as in our patient. Some authors recommend avoiding cautery when necrosis is suspected because of the high risk of perforations, and prefer using hemoclips, which are safer ${ }^{4}$. 
The systemic hypoperfusion appears as gastric mucosal discoloration, loss of mucosal vascular pattern, diffuse erosions or ulcerations ${ }^{2-4}$. With reperfusion and possible superinfection, both acute and chronic inflammation become visible, and exudate or pseudomembrane may be evident endoscopically ${ }^{4}$.

In patients with clinical or radiological suspicious of GI, EGD should be performed in order to make a differential diagnose, estimate its severity and extension, and evaluate the possibility of endoscopic management. Some authors recommend classifying and estimating the grade and severity of GI based on its endoscopic appearance ${ }^{3}$. They classify in mild (mottled and pale gastric mucosa), moderate (mottled and pale gastric mucosa, numerous stellate gastric erosions or small ulcerations) or severe (moderate plus large and confluent gastric ulcerations) by the endoscopic findings.

Endoscopists usually make GI diagnosis according to endoscopic findings; unless these are atypical, extensive or suspicious of other diseases (malignancy, drug-induced ulceration or viral infection), biopsies are not obtained ${ }^{3,5}$. There is no agreement if biopsies are mandatory in the early EGD, because in the majority of cases the histological examination do not suggest the underlying cause. Early GI histological changes include capillary dilatation, mucosal edema, vascular congestion, and superficial necrosis, white mucosal coagulative necrosis and full-thickness haemorrhagic necrosis with deep ulceration of the gastric wall are seen at progresion ${ }^{3,4,6}$.

Patients are usually treated conservatively unless signs of perforation, sepsis or persistent bleeding (despite endoscopical intervention) are developed, in which case gastrectomy is warranted ${ }^{5}$. The medical management of GI includes fluid resuscitation, nasogastric tube as prevention of gastric distension that worsen the ischemia, intravenous proton pump inhibitors, and broad-spectrum antibiotics if sepsis or gastric pneumatosis are present. ${ }^{3}$

Angiographic interventions may be useful in vascular obstructive pathology, as in this case, in order to ensure the blood supply. The main techniques are angioplasty or vascular stenting ${ }^{6-9}$. Although stomach receives the main blood supply from the celiac artery, clinical improvement after revascularization of the superior mesenteric artery, and even the inferior mesenteric artery, has been documented ${ }^{7,8}$.

The endovascular approach depends on the setting (acute or chronic ischemia). Angiography can define the location of arterial occlusion and provides the potential for intervention, if mesenteric or GI is diagnosed prior to gastrointestinal infarction 9. Although percutaneous transluminal angioplasty and stenting is an alternative treatment in chronic mesenteric ischemia, its role in the acute setting is controversial $^{9}$. In acute thrombosis ischemia, even though other acknowledge management as selective catheterization and intra arterial thrombolysis is safe as an alternative to surgery, it is contraindicated in patients who had recent surgery, trauma or severe gastrointestinal haemorrhage ${ }^{9}$.

In our patient, the previous comorbidities and the loading dose of clopidogrel prior to the stent may play a role in both the reperfusion and the development of a new haemorrhage. Despite aggressive management and optimal supportive care, GI has a poor prognosis and, as in acute mesenteric ischemia, the mortality rate is high $(64-93 \%)^{8,9}$. An early diagnosis is critical to guide potential interventions $s^{4,7}$.

In conclusion, GI should be suspected in individuals with underlying vascular, predisposing condition for vascular compromise, non-NSAIDs (non-steroid anti-inflammatory drug), ulcer not related to Helicobacter pylori, atypical lesion, ulcer refractoriness to standard peptic ulcer therapy, and severe recurrent hemorrhage ${ }^{4,5}$.

Although few cases have been reported, the clinical awareness of this syndrome will allow gastroenterologists, endoscopists and radiologist to appropriately diagnose and manage affected patients. Even with poor prognosis, we have some options of endoscopic and revasculization management that may lead to higher rates of success $s^{2-4,7}$. 


\section{REFERENCES}

1. Guniganti P, Bradenham CH, Raptis C, Menias CO, MeLlnICK VM. CT of gastric emergencies. Radiographics 2015; 35: 1909-1921.

2. Ahmad DS, SAHAK K, Lazenby AJ, Bhat I. Chronic mesenteric ischemia and gastric ischemia: a bad combination. Gastrointest Endosc 2017; 86: 564-565.

3. Tang SJ, Daram SR, Wu R, Bhaijee F. Pathogenesis, diagnosis, and management of gastric ischemia. Clin Gastroenterol Hepatol 2014; 12: 246-252.

4. Herman J, Chavalitdhamrong D, Jensen DM, Cortina G, Manuyakorn A, Jutabha R. The significance of gastric and duodenal histological ischemia reported on endoscopic biopsy. Endoscopy 2011; 43: 365-368.
5. Papanikolaou IS, Foukas PG, Sioulas A, Beintaris I, Panagopoulos P, Karamanolis $\mathrm{G}$ et al. A case of gastric ischemic necrosis. Endoscopy 2011; 43: E342.

6. HuAng G, Jin Y. Total gastric necrosis: A case report and literature review. Niger $\mathrm{J}$ Clin Pract 2017; 20: 645-646.

7. Mercogliano G, Tully O, Schmidt D. Gastric ischemia treated with superior mesenteric artery revascularization. Clin Gastroenterol Hepatol 2007; 5: A26.

8. Patel VK, Barrison I, Jackson J, Catnach S. Gastric ulceration due to chronic mesenteric ischemia treated by stenting of the inferior mesenteric artery. Gut 2005; 54: 888-889.

9. Demirpolat G, Oran I, Tamsel S, Parildar M, Memis A. Acute mesenteric ischemia: endovascular therapy. Abdom Imaging 2007; 32: 299-303. 
